\title{
The Distant Promise of a Negotiated Justice
}

\author{
Leslie Vinjamuri
}

\begin{abstract}
A basic dilemma for political transitions and peace talks, whether to hold perpetrators of mass atrocities accountable or to negotiate a deal, has once again become the source of intense political controversy. Originally seen as containing a pathbreaking and innovative solution to this problem, a peace deal designed to bring an end to the war between the government of Colombia and the FARC was instrumentalized by former President Uribe to mobilize popular support and was struck down when it was put to the public for a vote. Elsewhere, political realities have impinged on efforts to hold trials, provoking a backlash by powerful individuals determined to spoil the peace rather than sacrifice their personal freedom. But when international criminal tribunals fail to prosecute powerful spoilers, they have been condemned for their hypocrisy or charged with being selective in their pursuit of justice. One measure to address the basic accountability dilemma would be to accept transitional justice compromises that hold a reasonable prospect of delivering peace and that have a strong base of support among those individuals and communities most affected by political violence. Transitional justice strategies should be guided by a dono-harm principle.
\end{abstract}

LESLIE VINJAMURI is Associate Professor of International Relations and Director of the Centre on Conflict, Rights and Justice at SOAS, University of London. She is the coeditor of Human Rights Futures (2017) and has published in such journals as International Security, Eth$i c s$ and International Affairs, Annual Review of Political Science, and International Journal of Transitional Justice. She is a trustee of Chatham House, the Royal Institute of International Affairs, and is on the Advisory Board of LSE IDEAS.
F ourteen years ago, in the pages of this journal, Jack Goldsmith and Stephen Krasner wrote about the limits of an idealism that would disassociate the search for justice from sovereignty, national security, and power politics. ${ }^{1}$ In that same year, Jack Snyder and I wrote that holding war crime trials in states with powerful spoilers and weak institutions risked provoking a backlash. ${ }^{2}$ These warnings, grounded in a logic that stressed the consequences of political action, built on the work of Samuel Huntington, who, in his book Third Wave, identified the potential for a backlash if war crimes trials were held in countries where the military retained significant power. ${ }^{3}$

Despite these cautionary notes, the effort to build and consolidate institutions around a rules-based logic designed to secure the prospect of criminal accountability for international crimes has forged ahead:

C 2017 by the American Academy of Arts \& Sciences doi:10.1162/DAED_a_oo425 
many of the rules and procedures that govern the International Criminal Court (ICC) have been formalized; important principles such as complementarity and the interests of justice have been given more clarity; and practices for guiding preliminary examinations have been formalized. Since 2002, the Court has opened ten formal investigations ("situations"), and begun at least as many preliminary investigations. It has publicly issued thirty-nine arrest warrants or summonses to appear (and potentially more under seal), including against heads of state. Far beyond the remit of the ICC, the tide of justice has also been rising. Legal challenges against high profile amnesties in Latin America succeeded, opening the door to human rights trials for atrocities committed under military dictatorships in Argentina and Chile. Mixed and ad hoc tribunals have also contributed to what leading human rights scholar Kathryn Sikkink has called a "justice cascade." 4

The ICC has played a critical role in altering expectations for international justice among elites, civil society organizations, and the perpetrators of mass atrocities, even in highly unstable and violent contexts. Peace negotiators and international diplomats think differently about peace talks today than they did two decades ago. Formal amnesties that explicitly refer to international crimes are now widely acknowledged to be off the table.

There has also been considerable effort to clarify formal rules governing possible exceptions to ICC justice, namely those pertaining to deferrals, complementarity, and the decision to abstain from proceedings if they do not serve the interests of justice. Once merely words on a piece of paper, these rules have received considerable attention. ${ }^{5}$ Rather than making exceptions on an ad hoc basis, the ICC has sought to design rules to govern exceptions.

Some of these rules are based on a logic of consequences. The Security Council can defer a case for a twelve-month (renew- Leslie able) period if it agrees there is a threat to Vinjamuri peace and security. But most of the rules that the ICC draws on to govern exceptions follow a different logic. Consequentialism doesn't underpin the complementarity principle, which dictates that the ICC will only consider cases when a country is not willing or able to hold individual perpetrators accountable at home. The ICC can also decide that a case is inadmissible if it is not in the interests of justice to pursue it. The "interests of justice" have been interpreted to refer to the interests of victims, not the consequences for peace. But the meaning of the interests of justice remains the source of considerable debate. Some argue that this should include a consideration of the interests of society at large, which would provide one route for the prosecutor's office to formally consider the impact of justice on peace.

One result of the effort to further clarify and confirm the rules has been to narrow the scope for exceptions to be granted. The bar for sidestepping international justice is now far higher. To some, it may seem that little if any room has been left for compromise and negotiation in the face of difficult trade-offs.

This sea change in the institutions, laws, and rules designed to ensure accountability has yet to produce similar changes on the ground. The gap between principle and practice is pronounced. Enforcement and compliance are subject to politics, power, and sovereignty. ${ }^{6}$ Public officials have proved reluctant to subject themselves to international scrutiny. Liberal democracies, where the rule of law and human rights principles are well established, may support international justice for others, but prefer to deal with accountability issues at home. After the United States was reported to have bombed a hospital in Afghanistan populated by Médecins sans Frontières (MSF) workers and civilians, MSF demand- 
The Distant ed that an international commission conPromise of a Negotiated Justice duct investigations. ${ }^{7}$ Instead, the Pentagon proceeded with an internal investigation. ${ }^{8}$ When domestic procedures fall short of international expectations, democracies have asserted their sovereignty. The United States deflected international and domestic demands for trials of individuals responsible for the CIA's torture program..$^{9}$ In 2014, the Senate conducted a formal investigation of the program resulting in the publication of a report, but there has been little follow-up since. ${ }^{10}$

Elsewhere, a backlash against international efforts to investigate state elites has taken root. The decision by South Africa to withdraw from the ICC came within months of a visit by the President of Sudan. During this visit, South Africa came under intense pressure to send President Bashir to The Hague and was condemned for refusing to do so. Nonstate actors that cooperate with investigators and tribunal officials have risked their personal and organizational security. Refugees that cooperated with the ICC's investigations of Darfur also found themselves to be at risk of personal danger. Humanitarian NGOs that cooperated with the ICC's investigations of atrocities in Darfur were expelled. Similarly, witnesses that were called to the ICC from Kenya were intimidated. State elites also waged an aggressive campaign against the Court. Kenya's elites put up the fiercest protests of all, successfully forging a cross-ethnic alliance designed to secure the presidency on the back of an antiICC campaign. They then proceeded to build a cross-Africa protest coalition using the vehicle of the African Union to protest against the ICC's targeting of sitting heads of state.

The impasse between principle and politics has created a political environment marked by uncertainty. Although the ICC has formalized rules to govern exceptions, exceptions to the rules have, in practice, more often been driven by politics that take place beyond the ICC. In many cases, the ability of spoilers to block the ICC's efforts to conduct investigations and to prevent arrests has been the ticket to a free pass. This political reality raises a crucial question: are there circumstances under which transitional justice deals should be accepted for principled and pragmatic reasons, and if there are, who should decide this?

The announcement of a peace deal between FARC rebels and the government of Colombia brought this dilemma to the fore. ${ }^{11}$ The arrangement turned on the negotiation of a transitional justice deal, the "special jurisdiction for peace." FARC rebels would be offered lighter sentences, including an element of community service, in exchange for a confession of their wrongdoings. The Colombian deal was subject to three checks: the Constitutional Court, a public referendum, and the International Criminal Court. Colombia had been under preliminary examination by the ICC since 2006. Ultimately, it was electoral politics and a national plebiscite, not the ICC, that jettisoned the deal.

In this essay, I demonstrate how a backlash against international justice has created a gap between principles and practice. Powerful state actors have sought to limit the scope of justice, sometimes by rewriting the rules or seeking to displace the authority of existing institutions with alternatives that they can more effectively control. Sequencing and negotiation are two frameworks that have shaped thinking about how to address this dilemma. Sequencing proposals assume that the timing and phasing of peace and justice strategies can help resolve the tension between principle and practice, in part by helping to overcome the tension between securing peace and promoting justice. A second framework stresses the importance of negotiating transitional justice deals. One key question in considering these frame- 
works is what ethical standards should be used to determine the role for justice and accountability in any given situation.

I advance three arguments about the optimal role of investigations and war crimes trials in transitional contexts. First, a dono-harm principle should guide decisions about justice and accountability, especially in transitional contexts. Second, proposals that recognize the need for compromise must not be ruled out. Sequencing is an inadequate framework for dealing with the need for justice and accountability in transitional contexts because it emphasizes the need to adjust the timing of established frameworks, but not the content. In fact, compromise on the substance and form of justice and accountability measures is often necessary. Third, the international community and especially the ICC should recognize the legitimacy of transitional justice compromises, especially when domestic support for these deals extends beyond their direct beneficiaries to include those most affected by political violence.

$\mathrm{H}_{\mathrm{i}}$ istorically, trials have been rare and, until recently, the assumption that peace must precede the pursuit of justice and that victorious powers would determine the course of justice has been unchallenged. Political elites also preferred to defer justice until after war's end to prevent a possible retaliation against their own prisoners of war. ${ }^{12}$ Political considerations have also shaped the trajectory of ongoing justice initiatives. After 1945, American leaders were determined to build a strong multilateral alliance system with Western Europe to counter Soviet power. Over time, American leaders feared that antagonizing West Germany would undermine their broader strategic objectives. By the mid1950s, the United States concluded its trials of German war criminals and put in place a clemency program that led to the early release of large numbers of them. ${ }^{13}$
Elites facing internal political transi- Leslie tions have made similar calculations. Transitions away from authoritarianism have rarely included trials of high-ranking officials. In Brazil, an amnesty was used to secure the military's buy-in as part of the transition. Argentina quickly backtracked after an initial attempt to put military leaders on trial. To prevent a military coup, it too adopted an amnesty. ${ }^{14}$ General Pinochet approved his own amnesty as part of Chile's transition away from military rule. Amnesty also has a long history throughout Africa. ${ }^{15}$ Even in South Africa, where the truth and reconciliation commission quickly gained global recognition, the transition hinged on a deal that the Amnesty Committee was obliged to grant amnesty if certain criteria were fulfilled, most especially that an individual perpetrator confessed his crimes, including a full disclosure of all relevant facts.

Transitions in Latin America spurred new legal thinking. The idea that there was a moral and legal duty to prosecute certain international crimes regardless of the constraints of sovereignty, conflict, or political transition quickly gained traction. ${ }^{16} \mathrm{In}$ the summer of 1992, war crimes in the Balkans, and especially the discovery of detention camps, inspired a coalition of journalists and human rights advocates to demand prosecutions for the perpetrators of these mass atrocities. ${ }^{17}$

In the spring of 1993, the United Nations Security Council passed a resolution to create the International Tribunal for the former Yugoslavia (ICTY) to prosecute international crimes in the former Yugoslavia. One year later, a similar ad hoc tribunal was created to prosecute perpetrators of the atrocities in the Rwandan genocide. By 1998, the Rome Statute created the basis for an institutionalized set of rules and procedures for criminal accountability and within a few years, the ICC had received the necessary sixty ratifications. In 2002, it 
The Distant became the first permanent international Promise of a war crimes court.

Negotiated Justice

1 he surge of advocacy and institutions for accountability signaled a principled commitment to justice by a highly motivated and mobilized network of advocates in both the private and public sphere that extended across many states, predominantly but not exclusively in Europe, Latin America, and North America. Advocates have been optimistic that this would have positive effects for justice, accountability, and even peace. Perhaps the most enthusiastic and optimistic of the leading international NGOs, Human Rights Watch, has argued for the power of arrest warrants and trials to stigmatize targeted individuals. ${ }^{18}$

But the surge in principled advocacy has not been matched by a change in political realities. Consequently, the gap between principle and practice has widened. In the 1990s, the use of amnesty increased as did the number of civil wars, many of which were resolved through negotiation rather than military victories on the battlefield. ${ }^{19}$ Increasingly, though, international peace negotiators now opt for a "strategic silence" in peace talks and peace agreements. The normative prohibition on amnesties has created a precarious balance between justice and peace. Amnesties for international crimes (genocide, crimes against humanity, and war crimes) are less common, but this has not translated into a commitment by belligerents to cooperate in prosecuting these crimes. ${ }^{20}$

In the face of concrete justice initiatives, the targets of international justice have sought to deflect or reject investigations or arrests from taking place inside their borders. Even when governments have formally agreed to cooperate with the ICC, their actual behavior has sometimes oscillated. Uganda invited the ICC to investigate war crimes committed by Lord's Resistance Army (LRA) rebels, but with the caveat that it would not cooperate with ICC proceedings against state actors. ${ }^{21}$ When faced with the quandary that ICC arrest warrants might impede the success of peace talks in Juba, the government did an about-face, asserting that it preferred that the Court drop its case and allow talks with the LRA to proceed unhindered. ${ }^{22}$

One of the most commonly cited success stories for justice intervention is the case of Charles Taylor, former president of Liberia. An arrest warrant against Taylor issued by the Special Court for Sierra Leone was unsealed on the first day of peace talks on the Liberian war. Taylor left the peace talks and was later prosecuted and convicted for war crimes at a trial in The Hague. But although Taylor left the peace talks, what is usually left out of this story are the circumstances under which he agreed to go. Taylor left not with the assumption that he would be prosecuted, but rather under the belief that he would be protected. After returning to Monrovia, he later went to Nigeria for what was intimated to him to be an indefinite asylum. ${ }^{23}$ Taylor's trial and subsequent conviction most likely made other leaders wary and less willing to step aside when faced with the prospect of an arrest. ${ }^{24}$

The backlash against international justice has been especially intense in those places where the ICC was never welcome in the first place. Security Council referrals of nonmembers have not been well received. Nor have investigations initiated by the prosecutor, as Kenya has shown. In these situations, uncompromising justice meted out against powerful spoilers has neither neutralized its targets nor weakened the resolve of their allies. Elites that have come under the purview of the ICC have adopted an array of tactics designed to court allies and undermine investigations. Sudan's President Bashir decided to stand for reelection when he learned that there was an arrest warrant against him, effectively jettisoning his previous plan to retire. ${ }^{25}$ First, 
though, he forced the exit of leading international humanitarian organizations that he suspected of assisting ICC investigators by giving evidence against him. The arrest warrant against Libya's leader, Muammar Gadaffi, also failed to diminish his determination to fight. At the same time, the one-sided nature of ICC investigations in Libya may have bolstered the confidence of rebel fighters whose crimes were effectively ignored by the Court. ${ }^{26}$

In Kenya, the ICC had an even greater impact, effectively inspiring two of its targets to form a coalition and campaign for the presidency on an anti-ICC platform. The Kenyatta-Ruto campaign cast the ICC as an instrument of Western imperialism, making the ICC one of the key election issues. After successfully taking the presidency and vice presidency, Kenyatta and Ruto went on to challenge the legitimacy of the ICC and undermine its case against them, primarily by intimidating witnesses. This strategy worked. In December 2014, Chief Prosecutor Bensouda declared that the ICC lacked sufficient evidence and so could not proceed with the case against President Kenyatta.

States have also been reluctant to support justice in the absence of either a transition plan or successful peace talks. For a full year, the U.S. government refused to support a call by European leaders to refer Syria to the ICC. European leaders had committed to a unified effort, but privately, some European governments acknowledged that they took comfort knowing they could name and shame Syria and talk about justice, but be secure in the reality that in the absence of U.S. support, peace diplomacy could proceed without risk of interference. The U.S. position changed only after a second round of peace talks failed. The release of photographic evidence documenting mass atrocities in Syria spurred the U.S. government to support a French-led initiative to draft a resolution calling for Syria's referral to the ICC.
The resolution was vetoed by Russia and Leslie China.

Vinjamuri

One strategy to move beyond this impasse is to agree to a set of rules or ideals for closing the gap between principle and practice. This raises a prior question: what is the ethical standard for agreeing to such a principle? I recommend that a dono-harm standard should guide decisions about international justice. In the contemporary political, legal, and normative environment, this standard balances what is practically achievable with optimal results. By this standard, the pursuit of justice should not impede the prospects for achieving peace. Compromises of justice intended to save lives by ending war are acceptable. Similarly, amnesty would be acceptable if it helps secure a democratic transition, away from authoritarian rule that is associated with human rights abuses. In practice, the application of a do-noharm standard might guard against unenforceable arrest warrants targeted against powerful spoilers, especially sitting heads of state, but it would not preclude efforts to collect evidence and document crimes either by NGOs like the Commission for International Justice and Accountability, by the UN Commission of Inquiry, which has documented human rights abuses in states such as North Korea, or by the International Criminal Court. ${ }^{27}$

Positive effects, a second possible standard, sets a higher bar. By this standard, justice should be pursued only when it will have positive effects for peace, democracy, and human rights. ${ }^{28}$ A positive effects standard would consider the immediate impact on a particular situation, but also balance this with the medium- and long-term effects of justice and accountability. One potentially positive effect of trading off justice in the short-term might be to secure a peace deal that empowers a reform coalition's institution-building efforts in the 
The Distant long run. In an ideal world, the threat to Promise of a Negotiated Justice

prosecute and the promise to strike a transitional justice deal would be harnessed as part of a transitional strategy. In the existing normative, legal, and institutional environment, applying this standard is more difficult than it used to be, but still possible. For many observers, Colombia's peace deal seemed to strike an important compromise, inserting accountability into the peace process but accepting a deal that offered the prospect of ending a war that had run for more than fifty years.

A third standard, last resort, requires that all alternative policy instruments be deployed to avoid the resort to war (or to bring a halt to the continuation of war). This would include amnesties or safe exits. A promise of amnesty could be paired with a threat to prosecute if perpetrators failed to abandon their war-fighting aims. If the strategic use of amnesty or safe exits fails to secure peace, then a last resort standard would allow for the pursuit of justice regardless the consequences. In the aftermath of the second round of failed peace talks at Geneva, and prompted by the release of photographic evidence documenting mass atrocities in Syria, the United States decided to back a French-led initiative to draft a resolution calling for Syria's referral to the ICC. ${ }^{29}$

If an offer of amnesty enabled peace, though, a last resort standard would permit this exception. But if a safe exit were as likely to secure peace as an amnesty, then this would be preferable on moral as well as legal grounds. Unlike an amnesty, a safe exit offers no formal legal protection, but it has a similar ability to solve a short-term political problem by removing powerful spoilers. Human rights advocates accept the practice of safe exits, but have rejected amnesty for international crimes. During the NATO bombing of Libya, former President of the Open Society Foundations Aryeh Neier suggested the possibility of a safe exit deal for Gaddafi, but rejected offering amnesty. ${ }^{30}$ In 2015, four years after the war in Syria began, Kenneth Roth, director of Human Rights Watch, argued that while amnesty must remain off the table, a safe exit could be arranged for Assad. ${ }^{31}$

In practice, the last resort standard will be difficult to implement. Policy instruments, like an amnesty or safe exit, that fail to work at one point may be successful at a later point when the facts on the ground change. Peace talks failed in Bosnia in 1993, but succeeded in 1995. If an arrest warrant against Milosevic had been issued in 1993 on the basis that it was a last resort, this may have undermined the success of the peace talks, in which Milosevic represented the Serbs and that resulted in the signing of the 1995 Dayton peace accords.

In the case of Syria, if the proposed Security Council Resolution had passed, this may have added an additional complication to efforts to deal with the conflict in Syria. Within months of this vote, the U.S. focus shifted to combatting the rise of the Islamic State. And in late September 2015, Russia entered the war as an ally of President Assad.

$\mathrm{I}_{\mathrm{n}}$ $n$ recent years, practitioners, advocates, and scholars have debated the optimal sequencing of international justice. This debate gained momentum surrounding the intervention in Libya. The juxtaposition of a Security Council referral of Libya to the ICC and, weeks later, NATO's military intervention instigated intense debate and division among human rights organizations about the role of the ICC in ongoing conflict. The ICC's role in Libya, especially its decision to issue an arrest warrant against Gaddaffi during NATO's air campaign, once again raised the question whether the threat to prosecute had a substantially negative effect on efforts to end the fighting. The African Union felt its own efforts to negotiate a settlement were hampered by the ICC arrest warrant. The de- 
cision by the ICC not to investigate rebel crimes was seen by some analysts as altering the dynamics of the conflict by emboldening rebel fighters. ${ }^{32}$

Sequencing proposals fall into three broad categories. First, proponents of a rights-first strategy call for integrating human rights and justice concerns into the front line of peace and security diplomacy and humanitarian initiatives. This strategy embodies a critique of the pragmatism of negotiations or humanitarian initiatives that have either taken human rights concerns off the table to secure access or negotiate a deal, or deferred them until peace and security goals are achieved.

Second, peace-first proposals essentially recommend that human rights and accountability concerns be deferred until peace has been secured either through the use of military force or through negotiations. Historically, amnesty has been an instrument that is integral to the peacefirst approach. More recently, because of the normative prohibition against amnesty for genocide, crimes against humanity, and war crimes, negotiators have generally adopted either a "strategic silence" for international crimes, or an amnesty that in theory does not apply to international crimes, but in practice might.

Third, separate tracks - the antisequencing proposal - rejects a focus on the strategic consequences of investments in peace and justice. Louise Arbour, former chief prosecutor of the ICTY and former high commissioner for human rights at the United Nations, coined this term after NATO's war in Libya had ended. In a speech during her tenure as president of Crisis Group, Arbour called for separate tracks arguing that the inevitable conflicts that arose between separate tracks should be resolved through ongoing compromise. ${ }^{33}$ Justice proponents and practitioners must not make exceptions in order to achieve peace and, similarly, peace practitioners must set aside any consideration of how their efforts will af- Leslie fect the prospects for justice. Only when the trade-offs are inevitable should they be negotiated, although proponents of this view have given few guidelines for how to approach these trade-offs. International justice and peace talks are two separate tracks that must be pursued independently and without consideration of the other. Separate tracks rejects a strategic approach to the pursuit of justice whereby threats to investigate or prosecute are matched by a promise of a safe exit or even amnesty if perpetrators of atrocities agree to stop fighting. It calls for preserving the independence of international tribunals from political influence both in practice and in institutional form.

Sequencing proposals are primarily concerned with timing and give inadequate consideration to the need for compromise and for deals. For this reason, they are ultimately inadequate for dealing with the real challenge of transitional justice. In many cases, the more preferable deals consist of arrangements that are outside the bounds of narrowly conceived criminal justice standards. Still, three proposals in particular should be given serious consideration.

First, since the likelihood of bringing perpetrators to justice and securing a conviction during ongoing violent conflict is low, while the prospect that trials can derail peace talks is significant, the focus in this period should be limited to evidence collection. Ideally, this evidence should be collected in a fashion that allows it to be useable in trials, should these be pursued at a later date. Commissions that are established to collect facts should be given sufficient time to complete their work.

Second, preliminary examinations by the ICC have the potential to cast the shadow of justice on violent conflict situations. Ideally, such investigations should help steer parties toward a resolution of conflict that 
The Distant recognizes a role for accountability that is Promise of a Negotiated Justice

stabilizing and acceptable to the relevant parties. However, the utility of preliminary examinations will necessarily be qualified by a number of factors, including the timing and nature of the communications that the ICC delivers to relevant parties to peace talks, the timing of decisions about whether to proceed with formal investigations, and the criteria through which ultimate decisions are made on final arrangements. Preliminary examinations are potentially very significant beyond the specific events they consider because they send a more general signal about how the Court is likely to decide on matters of peace and justice.

Third, diplomatic threats to prosecute specific individuals for war crimes may be paired with promises, should behavior change. This could be useful during violent conflict situations. Arrest warrants lack the flexibility of diplomacy and narrow the scope for bargaining, thereby removing the incentive that perpetrators of atrocities have to cooperate. Little if any precedent exists to suggest these provide a constructive way forward that meets a do-no-harm standard.

Ex xisting debate about sequencing among practitioners of international justice have ultimately been inadequate, failing to provide a solution to some of the most intractable peace and justice dilemmas. Instead, the international community, including the ICC, should recognize the legitimacy of transitional justice compromises when they demonstrate a measure of domestic support that extends beyond those who directly benefit and especially when those most affected by violence support the deal.

Innovative solutions designed to bridge a gap between accountability and impunity and hold off ICC investigations not only face external scrutiny, but they may also struggle to survive the political maelstrom of electoral democracy. On September 24,
2015, President Santos of Colombia and the FARC rebel leader Timoleón Jiménez announced a major breakthrough in peace talks that sought to bring an end to a fiftyyear-old conflict. ${ }^{34}$ After three years of talks, a solution to one of the most sensitive issues, whether rebel fighters would face trial or receive an amnesty for their violent crimes, was agreed upon. Colombia had been under preliminary examination by the International Criminal Court since 2006. Public opinion in Colombia, stoked by former President Uribe, also opposed a blanket amnesty. Negotiators anticipated the public referendum and Colombia's Constitutional Court as two highly consequential checks on a peace deal. They understood that the prospect of securing a deal would plummet if they announced a blanket amnesty for the FARC. Equally, a peace agreement with uncompromising justice for the FARC stood little chance of success.

The deal that Colombia's leaders sought to deliver reflected these conflicting pressures, striking a cautious balance between peace and justice. It proposed a truth commission for high-ranking individual perpetrators. Those that confess their crimes were to receive alternative sentencing, including tasks as varied as community service or even academic study, while others would face full criminal trials. The deal was widely praised by international leaders. In 2015 , the ICC issued a statement acknowledging the deal and expressing its tentative support. 35 Its reaction to Colombia's deal reflected a heightened sensitivity to the precarious balance between the requirements of peace and the demand for justice. As one Court official remarked, "we do not want to be seen to be a spoiler to peace." 36

Despite widespread international support, the deal failed to survive, albeit by a narrow margin, in a public referendum. Human Rights Watch opposed the deal (as did a few notable individual human rights ad- 
vocates) and were quick to claim that the "no" vote was a vote against the transitional justice deal. ${ }^{37}$ And yet in those regions most affected by the violence, the public voted yes to peace, but turnout was low, in part because of the adverse conditions created by Hurricane Matthew.

T ransitional justice deals must satisfy belligerent parties, especially those with the power to spoil a deal, if they are to succeed. But the international community increasingly plays an important role in stabilizing these deals. Since 2002, the default position in the international community has been to assume that the rules for international justice and, by default, the exceptions to those rules are governed by the International Criminal Court. Decisions about whether to acknowledge and accept these deals should be based on a calculation of whether they are likely to stick, and also whether there is a broader basis for assuming the legitimacy of such deals. This decision should not be left solely in the hands of the ICC, in part because the ICC remains highly constrained by a fairly narrow set of rules for exercising this judgment, but also because those rules remain vague, undefined, and, to a large extent, opaque.

The case of Colombia shows that transitional justice remains intensely political. The prospect that an uncompromising peace deal will succeed is slight. But the decision to subject a negotiated deal to a public referendum laid bare the opportunity for political elites to turn transitional justice into an instrument that could be used to gain advantage in electoral politics. The optimal mechanisms for evaluating the legitimacy of exceptions must extend beyond the consequentialist logic of political realists but not so far that it risks undermining the prospects for peace and for progress.

It remains to be seen what criteria the ICC will use to evaluate and decide on fu- ture transitional justice deals. Technically, Leslie the ICC decides on the basis of the principle of complementarity and also the interest of justice, as mentioned in Article 53 of the Rome Statute..$^{88}$ Complementarity, the principle that states that the ICC will only take on cases that are not genuinely investigated or prosecuted domestically, has now been interpreted as requiring that a state that wishes to pursue justice itself must hold criminal trials of individuals accused of international crimes, rather than seeking any alternative form of accountability. 39

The interests of justice, the second possible avenue through which the ICC can recognize the legitimacy of transitional justice deals, remains the subject of continued debate among transitional justice scholars and advocates primarily because it is not well defined or understood. The policy paper issued by the prosecutor's office maintains that the interest of justice refers to the interests of victims, and that the interest of peace is not part of the interests of justice but is the preserve of the Security Council.

$\mathrm{F}$ Formal arrangements for bringing perpetrators of mass atrocities to account have enshrined and protected the principle of accountability and yet, in practice, powerful spoilers continue to present an obstacle to the realization of this principle. This has resulted in uncertainty and ambiguity about when the rules will be applied. And yet no revision to the current rules seems to be on the horizon. The referral of Libya to the International Criminal Court and the ensuing proximity between justice, humanitarian intervention, regime change, and the Security Council created a watershed moment for proponents of international justice, but the thinking it generated has not yet led to a new consensus on the role of justice in conflict and transition.

The current framework for securing international justice has proven inadequate. 
The Distant It has gone a considerable distance toPromise of a Negotiated Justice

ward changing expectations, disseminating norms, and consolidating institutional frameworks for justice. But in the most intractable cases of authoritarianism, conflict, and transition, there has been little justice. Where the ICC has pressed ahead, this has inspired a concerted backlash.

The structure of international justice has also inspired allegations of hypocrisy. Liberal democracies of the West remain beyond the purview of international justice, for the most part. Allegations of torture by U.S. officials have been investigated but not prosecuted. The ICC focuses disproportionately on Africa, while the scale of mass atrocities in Syria grows daily. Each of these individual critiques of justice can be answered, but taken together, the overall picture for international justice is dissatisfying. Two measures for building on existing institutions should be embraced: first, one that recognizes the legitimacy of negotiated transitional justice compromises, especially in contexts where this is important for securing a democratic transition or strengthening the prospect for peace; and second, one that defers arrest warrants for sitting heads of state until a strategy for ending violent conflict has been implemented. The legitimacy of transitional justice compromises should be based on its overall benefit for society, and on evidence of domestic approval beyond a narrow self-interested elite, especially where this includes those most affected by violence.

\section{ENDNOTES}

Author's Note: I would especially like to thank Sarah Nouwen, Scott Sagan, and Jack Snyder for their comments on this essay. I would also like to thank Lauren Dickey for her research assistance.

${ }^{1}$ Jack Goldsmith and Stephen D. Krasner, “The Limits of Idealism," Daedalus 132 (1) (Winter 2003): $47-63$.

2 Jack Snyder and Leslie Vinjamuri, "Trials and Errors: Principled and Pragmatism in Strategies of International Justice," International Security 28 (3) (Winter 2003/04): 5- 44.

3 Samuel P. Huntington, The Third Wave: Democratization in the Late Twentieth Century (Norman and London: University of Oklahoma Press, 1991).

${ }^{4}$ Kathryn Sikkink, The Justice Cascade: How Human Rights Prosecutions are Changing World Politics (New York: W. W. Norton \& Company, 2011).

5 On the definition of the interests of justice, see International Criminal Court, Policy Paper on the Interests of Justice (The Hague: International Criminal Court, September 2007), https://www .icc-cpi.int/NR/rdonlyres/772C95C9-F54D-4321-BFo9-73422BB23528/143640/ICCOTPInterests OfJustice.pdf.

${ }^{6}$ Leslie Vinjamuri and Jack Snyder, "Law and Politics in Transitional Justice," Annual Review of Political Science 18 (1) (2015): 303-327.

7 Mark Tran and Julian Borger, “Afghan Hospital Bombing: MSF Demands Investigation under Geneva Conventions,” The Guardian, October 7, 2015, https ://www.theguardian.com/world/2015/ oct/o7/afghan-hospital-bombing-msf-demands-investigation-under-geneva-conventions.

${ }^{8}$ Matthew Rosenberg, "Pentagon Details Chain of Errors in Strike on Afghan Hospital," The New York Times, April 29, 2016, http://www.nytimes.com/2016/04/30/world/asia/afghanistan -doctors-without-borders-hospital-strike.html. 
9 The ACLU makes five recommendations for accountability for torture. See American Civil Leslie Liberties Union, “Accountability for Torture," https://www.aclu.org/feature/accountability Vinjamuri -torture.

${ }^{10}$ Senate Select Committee on Intelligence, Committee Study of the Central Intelligence Agency's Detention and Interrogation Program (Washington, D.C.: United States Senate, 2014).

${ }^{11}$ Nicholas Casey, "FARC Rebels in Colombia Reach Cease-Fire Deal with Government," The New York Times, June 22, 2016, http://www.nytimes.com/2016/06/23/world/americas/colombia -farc-peace-deal-rebels-cease-fire-santos.html.

12 Gary J. Bass, Stay the Hand of Vengeance: The Politics of War Crimes Tribunals (Princeton, N.J. : Princeton University Press, 2000).

13 Peter Maguire, Law and War: International Law and American History (New York: Columbia University Press, 2000).

${ }^{14}$ Huntington, The Third Wave: Democratization in the Late Twentieth Century; and Carlos Santiago Nino, Radical Evil on Trial (New Haven, Conn. : Yale University Press, 1998).

15 Helena Cobban, Amnesty after Atrocity? Healing Nations after Genocide and War Crimes (St. Paul, Minn. : Paradigm, 2007).

16 This position has frequently been associated with Diane F. Orentlicher, "Settling Accounts: The Duty to Prosecute Human Rights Violations of a Prior Regime," Yale Law Journal (100) (1991): $2537-2615$.

17 Nina Bernstein, "Should War Reporters Testify, Too? A Recent Court Decision Helps Clarify the Issue but Does Not End the Debate," The New York Times, December 14, 2002, http :// www.nytimes.com/2002/12/14/arts/should-war-reporters-testify-too-recent-court-decision -helps-clarify-issue-but.html?pagewanted=all.

${ }^{18}$ Human Rights Watch, SellingJustice Short: Why Accountability Matters for Peace (New York: Human Rights Watch, 2009). Some leading scholars have also argued that ratifying the Rome Statute had led to a reduction of civilian killings. See, for example, Hyeran Jo and Beth Simmons, "Running the Numbers on ICC Deterrence: When Does it Actually Work?" Open Democracy, March 22, 2016, https://www.opendemocracy.net/openglobalrights/beth-simmons-hyeran -jo/running-numbers-on-icc-deterrence-when-does-it-actually-work.

19 Data on the use of amnesty show a steady increase in the 1990s, but this likely correlates with an increased number of civil wars. See Louise Mallinder, "Amnesties' Challenge to the Global Accountability Norm? Interpreting Regional and International Trends in Amnesty Enactment," in Amnesty in the Age of Human Rights Accountability: Comparative and International Perspectives, ed. Francesca Lessa and Leigh Payne (New York: Cambridge University Press, 2012), 69 - 96.

${ }^{20}$ Leslie Vinjamuri and Aaron Boesenecker, Peace Agreements and Accountability: Mapping Trends from 1980 to 2006 (Geneva: Centre Humanitarian Dialogue, 2007). Another common strategy has been to announce an amnesty that does not apply to international crimes, but refrains from holding trials. Lakhdar Brahimi, a chief architect of the Bonn Agreement, insisted that a paragraph granting amnesty be removed before the final text was confirmed. Barnett Rubin, "Transitional Justice in Afghanistan," lecture, School of Oriental and African Studies, London, February 3, 2003, http://www.soas.ac.uk/cccac/events/anthonyhyman/file25446.pdf See also Sarah Nouwen, Complementarity in the Line of Fire: The Catalysing Effect of the International Criminal Court in Uganda and Sudan (Cambridge: Cambridge University Press, 2013), 267.

${ }^{21}$ Nouwen, Complementarity in the Line of Fire.

${ }^{22}$ Michael Wilkerson and Frank Nyakairu, “Uganda: Museveni Offers Kony Amnesty,” The Monitor (Uganda), July 4, 2006, http://allafrica.com/stories/200607040115.html.

23 Wilton Park, "Negotiating Justice: The Challenge of Justice and Accountability in Peace Negotiations," Report on Wilton Park Conference WPS10/o4, September 2010, https://www .wiltonpark.org.uk/wp-content/uploads/s10-04-report.pdf. 
The Distant Promise of a Negotiated

Justice ${ }^{26}$ Priscilla Hayner, "Libya: The ICC Enters during War," International Justice and the Prevention of Atrocities (London: European Council on Foreign Relations, 2013), http://www.ecfr.eu/ijp/ case/libya.

27 United Nations Human Rights Office of the High Commissioner, "Report of the Commission of Inquiry on Human Rights in the Democratic People's Republic of Korea," http://www .ohchr.org/EN/HRBodies/HRC/CoIDPRK/Pages/ReportoftheCommissionofInquiryDPRK.aspx.

${ }^{28}$ Rianne Letschert and Marc Groenhuijsen, "Not Everyone Thinks the ICC in Syria is a Good Idea," Justice in Conflict, June 12, 2014, http://justiceinconflict.org/2014/o6/12/not-everyone -thinks-the-icc-in-syria-is-a-good-idea/; and Leslie Vinjamuri, "Syria and the International Criminal Court,” Political Violence @ a Glance, April 25, 2014, http://politicalviolenceata glance.org/2014/04/25/syria-and-the-international-criminal-court/.

${ }^{29}$ Colum Lynch, "Exclusive: Washington Cuts Funds for Investigating Bashar-Al-Assad's War Crimes," Foreign Policy, November 3, 2014, http://foreignpolicy.com/2014/11/o3/exclusive -washington-cuts-funds-for-investigating-bashar-al-assads-war-crimes/.

30 “Aryeh Neier on the Arab Revolutions," podcast, European Council on Foreign Relations, March 9, 2011, http:// www.ecfr.eu/content/entry/europe_and_the_arab_revolutions.

${ }^{31}$ Kenneth Roth, "Remarks at UN General Assembly Side-Event : Fleeing Assad's Barrel Bombs," United Nations, New York, September 28, 2015

${ }^{32}$ Hayner, "Libya: The ICC Enters during War."

33 Louise Arbour, "Doctrines Derailed? Internationalism's Uncertain Future," Global Briefing 2013, International Crisis Group, October 28, 2013, http ://old.crisisgroup.org/en/publication -type/speeches/2013/arbour-doctrines-derailed-internationalism-s-uncertain-future.html.

34 Ernesto Londoño, “The Prospect of Peace in Colombia," The New York Times, September 25, 2015, http://www.nytimes.com/2015/o9/26/opinion/the-prospect-of-peace-in-colombia.html.

35 Office of the Prosecutor, International Criminal Court, "Statement of the Prosecutor on the Agreement on the Creation of a Special Jurisdiction for Peace in Colombia," September 24, 2015, https ://www.icc-cpi.int/Pages/item.aspx ?name=otp_stat_24-09-2015.

${ }^{36}$ Private discussion between author and an International Criminal Court official, September 30, 2015 .

37 Human Rights Watch, "Dealing Away Justice: Government, FARC Agree to No Prison Time for Atrocities," September 28, 2015, https ://www.hrw.org/news/2015/o9/28/colombia-dealing -away-justice; and Paul Seils, "Devil Is in the Detail of Colombian Justice Deal," The World Post, October 15, 2015, http://www.huffingtonpost.com/paul-seils/devil-is-in-the-detail-of_b_ 8287172.html.

${ }^{38}$ International Criminal Court, "The Interests of Justice."

39 On complementarity, see Nouwen, Complementarity in the Line of Fire. 